\title{
Microbial load, physico-chemical properties, and organic acid profile of a naturally fermented carabeef, Pindang damulag, as affected by fermentation time
}

\author{
1,* Esteban, M.A.S., ${ }^{1}$ Mopera, L.E., ${ }^{2}$ Oliveros, M.C.R. and ${ }^{1}$ Dizon, E.I. \\ ${ }^{1}$ Institute of Food Science and Technology, College of Agriculture and Food Science, University of the \\ Philippines Los Baños, College, Laguna, Philippines 4031 \\ ${ }^{2}$ Institute of Animal Science, College of Agriculture and Food Science, University of the Philippines Los \\ Baños, College, Laguna, Philippines 4031
}

\begin{abstract}
Article history:
Received: 4 August 2019

Received in revised form: 25

September 2019

Accepted: 30 September 2019 Available Online: 7 October 2019
\end{abstract}

\section{Keywords:}

Enterococcus,

Lactic acid,

Native,

Traditional,

Weisella

DOI:

https://doi.org/10.26656/fr.2017.4(2).275

\begin{abstract}
Pindang damulag or fermented carabeef is a native traditional food from Pampanga, Philippines. It is produced by mixing thin slices of carabeef with curing ingredients, then storing the mixture in an anaerobic condition, and left through the action of naturally growing lactic acid bacteria (LAB) via fermentation for 1 week at room temperature. However, the practice of production and consumption of pindang damulag is slowly dying and there are only very limited scientific studies on pindang damulag. Therefore, the study aimed to identify the LAB present and determine its contribution to the microbial diversity, physico-chemical properties, and organic acid profile of pindang damulag during natural fermentation. During fermentation, standard serial dilution and plating show that all targeted groups of microorganisms (fungi, common bacteria, coliforms, acid producing bacteria and LAB) grew significantly until the $3^{\text {rd }}$ day. After day 3, only acid producing bacteria and $\mathrm{LAB}$ grew significantly. There was also a significant decrease in total soluble solids (TSS) from day 0 to day $3\left(30.31-28.17^{\circ} \mathrm{Brix}\right)$, while titratable acidity (TA) and $\mathrm{pH}$ were found to be statistically constant $(3.5 \%$ at $\mathrm{pH} 5.97-3.6 \%$ at $\mathrm{pH}$ 5.9). Moreover, significant decrease in TSS $\left(24.89,22.76\right.$, and $\left.20.53^{\circ} \mathrm{Brix}\right)$ and $\mathrm{pH}(5.60$, 4.93, and 4.53) were observed, while TA increased significantly $(4.5,5.6,6.6 \%)$ during days 5,7 , and 9 . After the culture dependent phenotypic and genotypic tests using $27 \mathrm{~F}$ and 1492R primer pairs, LAB isolates were found to be homologous to Enterococcus faecium and Weisella paramesenteroides. The former exhibited proteolytic activity on pindang damulag which broke down the protein chains with approximate MW of 20.1KDalton as observed in the acrylamide gel from SDS-PAGE. The other LAB was known to be a heterofermentative $\mathrm{LAB}$, which reflected on the predominance of other organic acids such as citric acid (448.70 mg/100 g), acetic acid (1724 mg/100 g) other than the lactic acid (4440 mg/100 g) alone, using RP-HPLC. Therefore, LAB was found to have a major role in the food safety, food quality and overall profile of pindang damulag.
\end{abstract}

\section{Introduction}

Water buffalo commonly known as carabao is one of the most important domesticated animals in the Philippines, aiding the farmers in plowing the fields, tilling the soil, and other farm duties that require heavy liftings. They are also abundant in the country, in fact according to the Philippines statistics authority - Bureau of Agricultural Statistics (2019) there were 2.87 million heads in the country as of the $1^{\text {st }}$ quarter of 2019 . This is higher compared to the 2.55 million cattle heads declared during the same period. However, carabao has a lower volume of production of 30.40 thousand metric tons, liveweight, less than half of the 61.31 thousand metric tons volume of production of cattle. One of the reasons is the negative connotation that carabeef (carabao beef) is tough and dry compared to beef. In the Philippines, most cattle for consumption are slaughtered at a younger age while, carabao is slaughtered at a later age because of the lower demand and their functions on the farm, hence tougher meat. However, many studies have compared beef from carabeef in terms of meat and carcass composition (Lapitan et al., 2008); proximate composition and intramuscular fatty acid profile (Oliveros et al., 2007); sensory characteristics, 
physicochemical and nutritional properties (Anjaneyulu et al., 1990). These studies, however, have shown that carabeef is not inferior to, but in fact highly comparable with beef, having a slight advantage in terms of tenderness, color, and flavor (Lapitan et al., 2008); significantly higher ash content, oleic acid content, and linoleic to linolenic acid ratio (Oliveros et al., 2007). Also, according to Philippine Statistics Authority Bureau of Agricultural Statistics (2019), carabeef costs a little cheaper at $\mathrm{PhP} 97.67$ than the $\mathrm{PhP} 108.50$ per kilogram liveweight of beef as of the $1^{\text {st }}$ quarter of 2019 . Hence, carabeef can be a cheaper yet competitive alternative/addition to the common carcasses for consumption.

The common carabeef dishes in the Philippines are kalderetang kalabaw (carabeef cooked in tomato sauce), ginataang kalabaw (cooked in coconut milk), tapang kalabaw (carabeef jerky), and bistek na kalabaw (carabeef steak). Pampanga, the province that has been dubbed as the "culinary capital of the Philippines", has a native traditional carabeef dish called pindang damulag (fermented carabeef). Pindang damulag (Figure 1) has a cured bright red color, glistening appearance due to the caramelized sugar, a meaty and sour fermented aroma, a juicy and chewy texture, and a very distinct flavor profile highly preferred by Kapampangans (people from Pampanga). In addition to this, the group of Banaay et al. (2013) and Sanchez (2008) enumerated a vast number of Filipino traditional fermented products wherein the dominant lactic acid bacteria (LAB) were identified and their role in the food safety and preservation of each were discussed. Generally, LAB predominates the microbial population and their lactic acid cause other groups of microorganisms especially pathogenic and spoilage microorganisms to reduce their growth, which eventually lengthens the shelf life of the product. For this reason, the practice of making each fermented food was passed down from one generation to another, especially in areas where access to food resources is difficult. However, in the case of pindang damulag most new

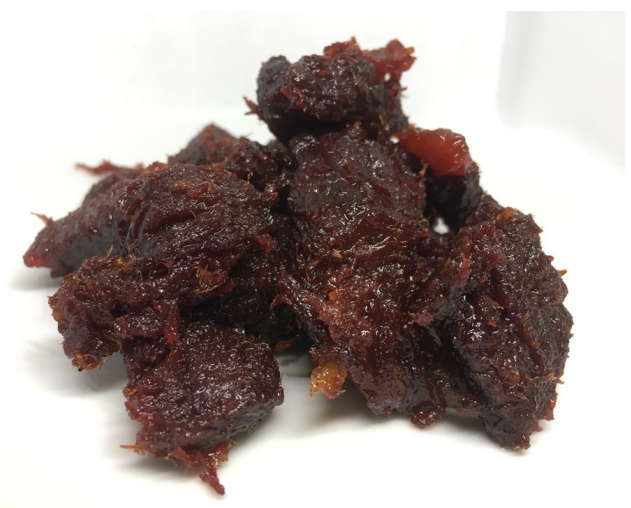

Figure 1. Pindang damulag slow cooked via deep frying in cooking oil. generation Kapampangans have only heard of this dish or do not know it at all. This traditional dish might eventually be forgotten, and ultimately the complex microflora and the physicochemical characteristics of pindang damulag that contribute to the unique profile of the dish might neither be replicated nor studied. Thus, this study was conducted to determine the microbial population of pindang damulag at different stages of natural fermentation and relate it to the physicochemical properties and organic acid profiles of pindang damulag.

\section{Materials and methods}

\subsection{Pindang damulag preparation}

The preparation of pindang damulag was based on the consolidated practices and formulations of known pindang damulag makers from the City of San Fernando, Pampanga, Philippines, along with minor modifications based on the food safety concerns of the researcher.

\subsubsection{Carabeef procurement}

The right hind leg of a newly slaughtered $60 \pm 3$ month-old carabao was obtained from the Philippine Carabao Center, University of the Philippines Los Baños, College, Laguna, Philippines. The carcass $\mathrm{pH}$ was taken at $15 \mathrm{mins}, 2 \mathrm{hrs}$, and $24 \mathrm{hrs}$ post-mortem to determine the carcass quality prior to processing. Upon determination of the carcass quality, the carabeef was fabricated into thin slices of approximately 0.25 inches thick and was stored in the chiller prior to curing.

\subsubsection{Curing and fermentation}

The refined washed sugar (15-18\%), rock salt (1.5$2 \%$ ), phosphate (1-1.5\%), and curing salt (1-1.5\%) were dissolved in chilled distilled water. The solution was then added to the carcass and was continuously mixed for 30 mins. The salted carabeef was distributed to 6 double-layered sterile polypropylene bags, each bag containing $500 \mathrm{~g}$ of meat sample. The air in each bag was manually removed, and the bags were sealed with maximum headspace as possible. The bags were then left to ferment for 9 days at room temperature $\left(28.75 \pm 0.75^{\circ}\right.$ C). One bag was opened to monitor the microbial load, physico-chemical properties, and organic acid profile during day $0,1,3,5,7$, and 9 of natural fermentation.

\subsection{Enumeration of selected groups of microorganisms}

The enumeration of different groups of microorganisms during the natural fermentation of pindang damulag were based on the standard conventional method of serial dilution and plating (BAM, 1998). About $25 \mathrm{~g}$ of randomly sampled pindang damulag was added to $225 \mathrm{~mL}$ of $0.85 \% \mathrm{NaCl}$ solution. It was then homogenized in a blender for 2 mins and 
transferred into a sterile container. The following media were used: potato dextrose agar (PDA) + chloramphenicol for yeast and molds; nutrient agar (NA) for common bacteria; glucose yeast peptone (GYP) agar $+\mathrm{CaCO}_{3}$ for acid producing bacteria; de Man Rogosa Sharpe (MRS) agar $+\mathrm{CaCO}_{3}$ for lactic acid bacteria; and violet-red bile agar (VRBA) for presumptive coliforms. All plating was done in triplicates. The PDA plates were incubated for 3 days at $30^{\circ} \mathrm{C}$; NA plates for 2 days at $30^{\circ}$ $\mathrm{C}$; GYP and MRS plates for 2 days at $37^{\circ} \mathrm{C}$; and VRBA for $16 \mathrm{hrs}$ at $30^{\circ} \mathrm{C}$. After incubation, the colonies were counted and were expressed in colony forming units per gram sample $(\mathrm{CFU} / \mathrm{g})$.

\subsection{Physico-chemical changes}

The test samples for physico-chemical analyses were prepared by mixing 1 part pindang damulag and 4 parts distilled water. The mixture was homogenized using a waring blender for 2 mins and set aside until further analysis.

\subsubsection{Total soluble solids}

On the prism of the refractometer (Atago 9314), two to three drops of the homogenized solution were placed. The total soluble solid of the sample was computed using the equation below and the reading was then expressed in degree brix ( ${ }^{\circ}$ Brix $)$.

TSS $\left({ }^{\circ} \mathrm{B}\right)=$ initial reading $\mathrm{X}$ dilution factor

\subsubsection{Titratable acidity}

Titratable acidity of the sample was determined following the modified method of Capita et al. (2006). The acidity was calculated and expressed as \% lactic acid using the formula:

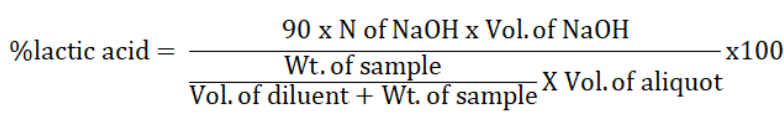

\subsection{3 $\mathrm{pH}$}

The $\mathrm{pH}$ values of the samples were determined using a calibrated pH-meter (Milwaukee 600).

\subsubsection{Moisture content}

The moisture content was computed based on the AOAC (2000) official method 950.46 moisture in meat.

\subsubsection{Color}

Color analysis expressed in the CIE $L^{*}, a^{*}$, and $b^{*}$ values were taken using a chromameter (Capsure ${ }^{\mathrm{TM}}$ Pantone ${ }^{\circledR}$ X-rite)

\subsection{Identification of lactic acid bacteria}

Colonies from MRS agar $+\mathrm{CaCO}_{3}$ plates were isolated and purified. The isolates were then screened phenotypically using standard physiological and biochemical tests. The lactic acid bacteria were then identified genotypically through a series of DNA extraction, polymerase chain reaction, 16s rRNA sequencing, and basic local alignment search tool. The primer pair used was 27F (AGA GTT TGA TCM TGG CTC AG) and 1492R (CGG TTA CCT TGT TAC GAC TT).

\subsection{Sarcoplasmic protein profile}

The determination of the sarcoplasmic protein profile during fermentation was determined using sodium dodecyl sulfate polyacrylamide gel electrophoresis (SDS-PAGE). One-part sample was added with 19 parts of ice-cold $1.1 \mathrm{M}$ potassium iodide in $0.1 \mathrm{M}$ phosphate buffered water $(\mathrm{pH} 7.2)$ to extract the sarcoplasmic protein of the sample. The solution was homogenized using a waring blender for 2 mins prior to centrifugation for $5 \mathrm{mins}$ at $4^{\circ} \mathrm{C}$ using $1500 \mathrm{x} \mathrm{g}$. The solution was then decanted, and the protein content was determined using Lowry method (Lowry et al., 1951; Joo et al., 1999; Waterborg, 2002). The solution was diluted further to a concentration of $25-250 \mu \mathrm{g}$ protein/g sample. The resulting solution was then subjected to SDS-PAGE to determine which of the polypeptides present was lost during fermentation based on their approximate molecular weight.

\subsection{Organic acid profile}

The sample preparation, system used, and chromatographic conditions for organic acid profiling was based on the modified methods of Jham et al. (2002), Olaye et al. (2008), Machado et al. (2008), and Nour et al. (2010).

\subsubsection{Organic acid standards}

The reference standards (lactic, acetic, succinic, and propionic acids) were prepared to a concentration of 100 $\mathrm{mg} / \mathrm{mL}$ stock solutions. Each solution was filtered through a $0.45 \mu \mathrm{m}$ membrane filter and was stored below $18^{\circ} \mathrm{C}$ until further use.

\subsubsection{Chromatographic system and conditions}

The HPLC system (Agilent 1260) was equipped with a C18 analytical column (Luna $5 \mathrm{u}, 250 \mathrm{~mm}$ length, 4.6 $\mathrm{mm}$ internal diameter); ultraviolet detector; and a data recorder (LC OpenLAB CDS). The analysis was performed at $50^{\circ} \mathrm{C}$, using a mobile phase consisting of $10 \mathrm{mM}$ perchloric acid in water at $\mathrm{pH} 2.1$ that was sonicated and filtered through $0.2 \mu \mathrm{m}$ membrane filter. It was then delivered at a flowrate of $0.7 \mathrm{~mL} / \mathrm{mins}$ for a run time of 30 mins per run. The eluted samples were 
detected by the UV detector set at $\lambda=214 \mathrm{~nm}$ with the sensitivity setting of 0.002 absorbance units full scale. The concentration of each organic acid was expressed as mg organic acid/100 g sample.

\subsection{Statistical Analysis}

The statistical design used was completely randomized design (CRD) with 3 replicates. All data obtained were statistically analyzed and interpreted using linear regression analysis and analysis of variance (ANOVA). Then Tukey's honest significance difference test was employed to locate the difference among the sample's parameters.

\section{Results and discussion}

\subsection{Microbial load of pindang damulag during natural fermentation}

Based on the regression analysis and ANOVA of the microbial load of pindang damulag during natural fermentation (Figure 2), all groups of microorganisms showed a significant increase in population from day 0 to day 3. However, from day 3 onwards, there was no significant increase in population for fungi, common bacteria, and presumptive coliforms. Acid producing bacteria and lactic acid bacteria, on the other hand, continued to increase significantly $(p<0.05)$ each observation day until the end of fermentation.

Meat has a complex nutrient composition containing almost all necessary nutrients which makes it an excellent substrate to allow a wide array of microorganisms to thrive especially at ambient conditions (Barbut, 2001; Cassens, 2008; Toldra, 2008). Hence, all groups of microorganisms grew significantly in the pindang damulag during the early stages of natural fermentation. However, from day 3 to day 9, there were observed changes in microbial population since some groups of microorganisms can co-exist in the same environment with other groups while some cannot (Ciani et al., 2008; Sumbali and Mehrotra, 2009). According to Wood and Holzapfel (1995) some groups of microorganisms such as acid-producing bacteria utilize carbohydrate sources and give off organic acids as the main end product of carbohydrate metabolism. Increased growth of acid producing bacteria translates to the relative increase in the production and accumulation of organic acids. Weak acids tend to remain undissociated in the substrate, which allows them to diffuse through the cell membrane. Upon reaching the cytoplasm, they will dissociate due to the near-neutral environment of the cytoplasm. The accumulation of anions in the cytoplasm affects the metabolic processes of the cell. The cell then expends energy to pump out the anions, leaving less energy for reproduction, hence slower growth rate and eventually death of other groups of microorganisms (Lahtinen et al., 2012). This phenomenon conforms with the results of the microbial analyses, wherein acid producing bacteria and lactic acid bacteria continued to grow significantly while fungi, common bacteria, and presumptive coliforms correspondingly reduced their growth rate from day 3 onwards.

\subsection{Physicochemical properties of pindang damulag during natural fermentation}

The total soluble solids (TSS) and $\mathrm{pH}$ of pindang damulag during natural fermentation significantly decreased $(p<0.05)$ while titratable acidity (TA) significantly increased $(\mathrm{p}<0.05)$ through time (Figure 3 ). TSS began to show a significant decrease during the $3 \mathrm{rd}$ day of fermentation and started to decline significantly each day until day 9, whereas $\mathrm{TA}$ and $\mathrm{pH}$ remained statistically constant up to day 3 and started to significantly increase and decrease, respectively, until the last day of fermentation.

During fermentation, acid producing microorganisms use carbohydrates from their environment (Wood and Holzapfel, 1995). In the case of pindang damulag, the added sugar in the form of sucrose considerably



Figure 2. Microbial diversity of pindang damulag during natural fermentation at $28.75 \pm 0.75^{\circ} \mathrm{C}$. Data points with the same letter per color are not significantly different at $(\mathrm{p} \leq 0.05)$ 
contributes as a carbohydrate source. According to Joshi et al. (2012), sucrose can be utilized during fermentations, but it needs to be broken down to simpler forms by invertase (sucrase) where it produces glucose and fructose or by sucrose phosphorylase to produce glucose-1-phosphate and fructose. Either way, all products are utilized via the glycolytic pathway. Hence, the significant decrease in TSS through time was caused by the significant increase in the number of acid producing bacteria and lactic acid bacteria, which utilizes sucrose during natural fermentation of pindang damulag (Figure 3).

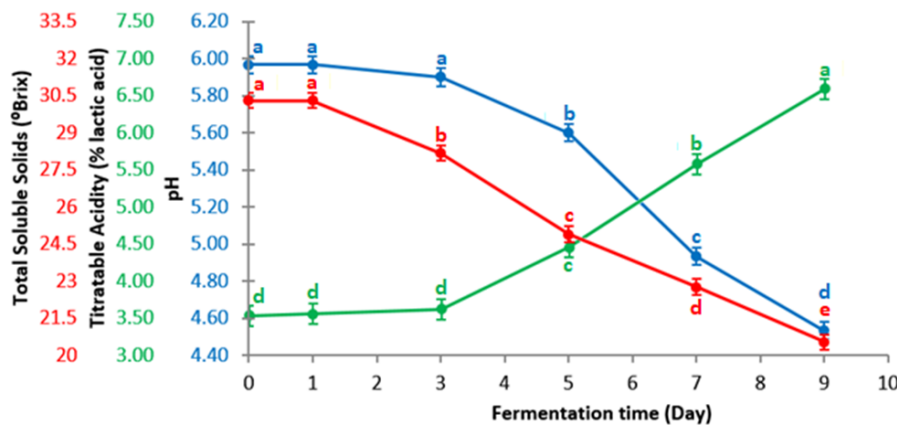

Figure 3. Changes in total soluble solids, titratable acidity, and $\mathrm{pH}$ of pindang damulag during natural fermentation at $28.75 \pm 0.75^{\circ} \mathrm{C}(\mathrm{p}<0.05)$. Data points with the same letter per color are not significantly different at $(\mathrm{p} \leq 0.05)$.

After the utilization of sucrose, acid producing microorganisms give off organic acids. Meat fermentations commonly exhibit lactic fermentation wherein the bacteria responsible mainly gives off lactic acid (Campbell-Platt and Cook, 1995; Toldra et al., 2014). Hence during fermentation of pindang damulag, significant production of lactic acid is relative to the significant decline in TSS (Figure 3). After the production of lactic acid in their environment, lactic acid eventually accumulates through time. The accumulation of these acidic compounds leads to the acidification of the environment. Hence, the $\mathrm{pH}$ of pindang damulag decreases as the TA increases (Figure 3).

\subsection{Moisture content of pindang damulag during natural fermentation}

The moisture content of pindang damulag during natural fermentation had no significant difference, while there was a significant increase in moisture content from day 0 to day 1 and remained constant thereafter until the last day of fermentation (Table 1).

The moisture content of pindang damulag at day 0 was significantly lower compared to the succeeding days of fermentation. This can be attributed to the mechanical stress brought by mixing. The samples for day 0 were taken right after mixing unlike the samples for day 1 to 9 each were placed and sealed in polypropylene bags and left to ferment prior to analysis. According to Dikeman and Devine (2014) meat mixtures reabsorbs lost moisture or meat exudates in a certain stage after processing, called "resting period". In this case, the resting period was within 24 hours, hence the moisture content of pindang damulag during day 1 was significantly higher than day 0 and remained statistically constant from day 1 until the last day of fermentation.

\subsection{Color analysis of pindang damulag during natural fermentation}

The CIE $L^{*}, a^{*}, b^{*}$ values of pindang damulag during fermentation shows that the $L^{*}$ and $a^{*}$ values had a significant difference during fermentation $(\mathrm{p}<0.05)$, while, the $b^{*}$ values remained statistically constant ( $>0.05$ ) throughout fermentation (Table 1).

The significant decrease of the $L^{*}$ value of pindang damulag from day 0 to day 1 can be attributed to the reabsorption of exudates during the resting period. According to Simpson (2012), the exudate contains water-soluble hemoproteins or heme pigments which caused the pindang damulag to significantly darken. On the other hand, from day 1 onwards the $L^{*}$ value increased significantly. This is due to the decrease in $\mathrm{pH}$ of pindang damulag, as it approaches isoelectric point of $\mathrm{pH}$ 5.5, the protein charge repulsion and the water holding capacity in the carcass decreases causing water molecules to be squeezed towards the surface. Therefore, when the incident light hits the surface of the pindang damulag more light is reflected causing the $L^{*}$ value to increase.

The significant increase of the $a^{*}$ value from day 0

Table 1. Moisture content and CIE L*, $\mathrm{a}^{*}, \mathrm{~b}^{*}$ values of pindang damulag during natural fermentation at $28.75 \pm 0.75^{\circ} \mathrm{C}$.

\begin{tabular}{ccccc}
\hline Fermentation Time (Day) & Moisture Content (\%) & $L^{*}$ & $a^{*}$ & $b^{*}$ \\
\hline 0 & $64.58 \pm 1.51^{\mathrm{b}}$ & $26.99 \pm 0.24^{\mathrm{b}}$ & $10.92 \pm 0.34^{\mathrm{b}}$ & $9.28 \pm 0.25$ \\
1 & $66.20 \pm 1.20^{\mathrm{a}}$ & $23.48 \pm 0.31^{\mathrm{c}}$ & $16.90 \pm 0.35^{\mathrm{a}}$ & $10.20 \pm 0.31$ \\
3 & $65.92 \pm 1.13^{\mathrm{a}}$ & $28.60 \pm 0.22^{\mathrm{b}}$ & $18.12 \pm 1.88^{\mathrm{a}}$ & $8.52 \pm 0.13$ \\
5 & $65.64 \pm 0.92^{\mathrm{a}}$ & $28.36 \pm 0.20^{\mathrm{b}}$ & $16.14 \pm 0.16^{\mathrm{a}}$ & $8.02 \pm 0.15$ \\
7 & $65.64 \pm 0.86^{\mathrm{a}}$ & $34.12 \pm 0.28^{\mathrm{a}}$ & $17.42 \pm 0.14^{\mathrm{a}}$ & $9.02 \pm 0.24$ \\
9 & $65.64 \pm 0.84^{\mathrm{a}}$ & $34.48 \pm 0.27^{\mathrm{a}}$ & $17.77 \pm 0.17^{\mathrm{a}}$ & $9.79 \pm 0.15$ \\
\hline
\end{tabular}

Means \pm SD in the same column with the same letter are not significantly different at $(p \leq 0.05)$. $L^{*}$ value $=$ lightness; $a^{*}$ value $=$ greenness to redness; and $b^{*}$ value $=$ blueness to yellowness 


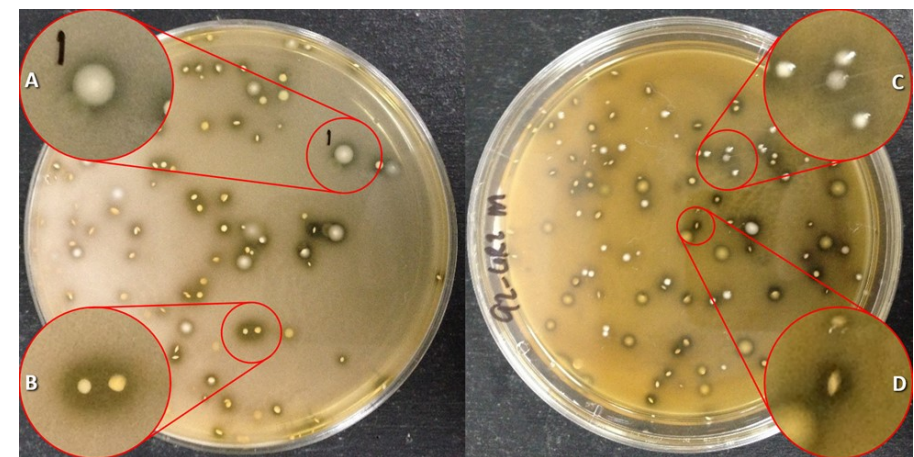

Figure 4. Morphological characteristics of colonies with clearing zones on MRS agar $+\mathrm{CaCO} 3$ incubated for $48 \mathrm{H}$ at $37^{\circ} \mathrm{C}$. (A) circular, translucent, white, matte, bottom. (B) circular, opaque, white, matte, bottom. (C) circular, translucent, white, shiny, top. (D) spindle-shaped, opaque, white, matte, bottom.

to day 1 can be attributed to the addition of sodium nitrite in the formulation which resulted to development of Nitric oxide (NO)-myoglobin complex which contributes to the red color of cured meat products (Pegg and Shahid, 2000). During day 1, the added curing salt has already reacted with the myoglobin available in pindang damulag resulting in the production of NOmyoglobin, which significantly increases the $a^{*}$ value of pindang damulag from 10.92 to 16.90 .

\subsection{Identification of lactic acid bacteria isolates}

After performing cultural characteristics on MRS agar $+\mathrm{CaCO}_{3}$, the colonies with clearing zones were grouped based on their colonial morphology (Figure 4). Physiological and biochemical tests screened only the Gram-positive and catalase-negative isolates. Genotypic identification using $27 \mathrm{~F}$ and $1492 \mathrm{R}$ primer pairs found that the isolates were homologous to E. faecium and $W$. paramesenteroides.

\subsection{Sarcoplasmic protein profile}

The protein profile resulting from the hydrolysis of muscle sarcoplasmic protein during natural fermentation is shown in Figure 5. It shows that as fermentation lengthens, the intensity of the band representing the sarcoplasmic protein with approximately $20.1 \mathrm{KDa}$ fades. The decrease in the intensity of the band was evident in all batches at day 3 onwards. The proteolytic activity can be contributed by the microorganisms present during fermentation. In the study of Fadda et al. (1999) where the researchers isolated Lactobacillus plantarum and discovered its effect on the protein components of the fermented sausages specifically at an approximate molecular weight of 97, 45, 37, and 26KDa. Similar to $L$. plantarum, one of the identified LAB specifically $E$. faecium is known to have a low to moderate proteolytic activity according to Abeijon et al. (2006) and Veljovic et al. (2009). Even though it only possesses a low to moderate proteolytic activity, due to their dominance, it



Figure 5. Sarcoplasmic protein profile of pindang damulag during fermentation at $13.5 \%$ acrylamide gel using Sodium Dodecyl Sulfate - Polyacrylamide Gel Electrophoresis (molecular weight marker followed by day 0 to day 9, from left to right). The $20.1 \mathrm{KDa}$ bands started to fade from days 5 to 9 .

can be assumed that the E. faecium contributed to the hydrolysis of the sarcoplasmic protein in the pindang damulag during fermentation. According to Zapelena et al. (1997) and Abeijon et al. (2006) hydrolysis of these protein components results in the formation of peptides and free amino acids, where the concentration or composition of each denotes a specific taste description. Toldra and Flores (1998) and Giraffa as cited by Batt (2014) also added that free amino acids are precursors of other volatile compounds which contribute to the aroma of the product. Hence, the identified LAB did not only decrease the growth of unwanted microorganisms, but its proteolytic activity also contributed to the unique characteristics of pindang damulag during fermentation.

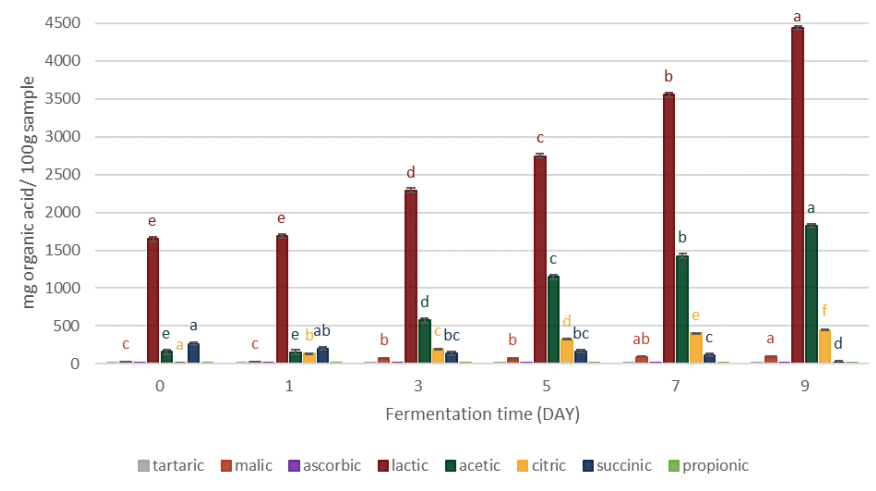

Figure 6. Organic acid profile of pindang damulag during natural fermentation at $28.75 \pm 0.75^{\circ} \mathrm{C}$. Lactic, acetic, and citric acid increases during natural fermentation while succinic acid decreases throughout fermentation $(\mathrm{p}<0.05)$. Data points with the same letter per color are not significantly different at $(p \leq 0.05)$

\subsection{Organic acid profile}

The organic acid profile of pindang damulag during natural fermentation is shown in Figure 6. Tartaric and propionic acid is below the limit of detection which is $2.00 \mathrm{mg} / 100 \mathrm{~g}$ and $4.00 \mathrm{mg} / 100 \mathrm{~g}$, respectively. All other organic acids significantly increased through time except for succinic acid which is similar to the study of Egelandsdal et al. (2006). According to this study, all 
organic acids lactic, acetic, citric, orotic, pyruvic, formic, uric, and propionic acid increased during fermentation while succinic acid decreased because it was eventually metabolized by bacteria.

Figure 6 shows that lactic acid dominated the organic acid composition of pindang damulag during fermentation. It was found to be statistically constant from day 0 to day 1 but the concentration increased significantly each day until the last day of fermentation. Meat fermentations are caused by LAB, which produces lactic acid as the main organic acid through carbohydrate metabolism. Furthermore, LAB counts dominated other types of microorganisms during the fermentation, hence as the number of LAB increases (Figure 2) the concentration of lactic acid proportionally increases (Figure 6).

Figure 6 also revealed that pindang damulag had a high concentration of acetic acid but lower than the lactic acid. It was constant from day 0 to day 1 but increased significantly thereafter until the last day of fermentation. Some LAB is heterofermentative which produces not only lactic acid during metabolism but also other compounds like acetic acid, $\mathrm{CO}_{2}$, and ethanol. The isolated $W$. paramesenteroides is known to be a heterofermentative $\mathrm{LAB}$ that contributes to the production of acetic acid in pindang damulag during fermentation.

\section{Conclusion}

The study shows that during the early stages of fermentation, pindang damulag has a varied population including coliforms and other unwanted microorganisms, which could render the pindang damulag at these stages to be unfit for human consumption. However, as the fermentation time proceeds, acid-producing groups of microorganisms continued to grow significantly. In line with this, the study also showed that the organic acid production of LAB through glycolysis and simultaneous carbohydrate utilization changed the physico-chemical properties of pindang damulag. These changes can inflict a combined effect of undissociated weak acids interfering with the metabolic processes of the cell and the accumulation of organic acids to lower the $\mathrm{pH}$ of the medium which, in theory, can cause other groups of microorganisms to show no significant increase in population and eventually increasing the food safety of the product while giving pindang damulag its unique profile.

\section{Acknowledgments}

The author would like to thank the Accelerated Science and Technology Human Resource Development
Program under the Department of Science and Technology (DOST-ASTHRDP) and the University Consortium Thesis grant given by the Southeast Asian Regional Center for Graduate Study and Research in Agriculture (SEARCA). The Institute of Food Science and Technology and the Institute of Animal Science are also acknowledged for the use of facilities and equipment.

\section{References}

Abeijon, M.C., Medina, R.B., Katz, M.B. and Gonzalez, S.N. (2006). Technological properties of Enterococcus faecium isolated from ewe's milk and cheese with importance for flavor development. Canadian Journal of Microbiology, 52(3), 237-245. https://doi.org/10.1139/w05-136

Anjaneyulu, A.S.R., Lakshmanan, V., Sharma, N. and Kondaiah, N. (1990). Buffalo meat production and meat quality: A review. Indian Food Packer, 44(4), 21-31.

AOAC. (2000). Official Method of Analysis. Vol. I and II. Washington, D.C.: Association of Official Analytical Chemist.

BAM. (1998). Bacteriological Analytical Manual, $8^{\text {th }}$ ed. Retrieved from FDA website: https://www.fda.gov/ food/laboratory-methods-food/bacteriologicalanalytical-manual-bam

Banaay, C.C.B., Balolong, M.P. and Elegado, F.B. (2013). Lactic acid bacteria in Philippine traditional fermented foods. IntechOpen [Online E-Book]. https://doi.org/10.5772/50582

Barbut, S. (2001). Poultry Product Processing: An Industry Guide., p. 315-377. Boca Raton, Florida, USA: CRC Press.

Batt, C.A. (2014). Encyclopedia of Food Microbiology., p. 674-679. London, UK: Academic Press.

Campbell-Platt, G. and Cook, P.E. (1995). Fermented Meats., p. 134. UK: Springer Science + Business Media. https://doi.org/10.1007/978-1-4615-2163-1

Cassens, R.G. (2008). Meat Preservation: Preventing Losses and Assuring Safety., p. 93-101. Connecticut, USA: Food \& Nutrition Press, Inc.

Ciani, M., Comitini, F. and Mannazzu, I. (2008). Encyclopedia of Ecology: Fermentation., p. 15481557. The Netherlands: Elsevier. https:// doi.org/10.1016/B978-008045405-4.00272-X

Dikeman, M. and Devine, C. (2014). Encyclopedia of Meat Sciences., p. 89. USA: Academic Press. USA.

Egelandsdal, B., Johannesen, T.C., Ekeberg, D., Bruun, T. and Slinde, E. (2006). Comparison of minke whale (Balenoptera acutorostrata) fermented sausage with more common salami products from 
pork and beef. $52^{\text {nd }}$ International Congress of Meat Science and Technology., p. 515-517. The Netherlands: Wageningen Academic Publishers.

Fadda, S., Sanz, Y., Vignolo, G., Aristoy, M.C., Oliver, G. and Toldra, F. (1999). Characterization of muscle sarcoplasmic and myofibrillar protein hydrolysis caused by Lactobacillus plantarum. American Society for Microbiology, 65(8), 3540-3546.

Jham, G.N., Fernandes, S.A., Garcia, C.F. and Da Silva, A.A. (2002). Comparison of GC and HPLC for the quantification of organic acids in coffee. Phytochemical Analysis, 13(2), 99-104. https:// doi.org/10.1002/pca.629

Joo, S.T., Kauffman, R.G., Kim, B.C. and Park, G.B. (1999). The relationship of sarcoplasmic and myofibrillar protein solubility to colour and water holding capacity in porcine longissimus muscle. Elsevier Meat Science, 52(3), 291-297. https:// doi.org/10.1016/S0309-1740(99)00005-4

Joshi, V.K., Walia, A. and Rana, N.S. (2012). Biomass Conversion: The Interface of Biotechnology, Chemistry, and Material Science., p. 251-312. Heidelberg, Berlin: Springer-Verlag. https:// doi.org/10.1007/978-3-642-28418-2_9

Lahtinen, S., Ouwehand, A.C., Salminen, S. and Wright, A.V. (2012). Lactic Acid Bacteria: Microbiological and Functional Aspects. $4^{\text {th }}$ ed., p. 1-6. Boca Raton, Florida, USA: CRC Press. https://doi.org/10.1201/ b11503

Lapitan, R.M., Del Barrio, A.N., Katsube, O., BanTokuda, T., Orden, E.A., Robles, A.Y., Cruz, L.C., Kanai, Y. and Fujihara, T. (2008). Comparison of carcass and meat characteristics of Brahman grade cattle (Bos indicus) and crossbred water buffalo (Bubalus bubalis) fed on high roughage diet. Animal Science Journal, 79(2), 210-217. https:// doi.org/10.1111/j.1740-0929.2008.00519.x

Lowry, O.H., Resebrough, N.J., Farr, A.L. and Randall, R.J. (1951). Protein measurement with Folin phenol reagent. Journal of Biological Chemistry, 193(1), 265-275.

Machado, D.I.S., Cervantes, J.L. and Cruz, O.M. (2008).Quantification of organic acids in fermented shrimp waste by HPLC. Food Technology and Biotechnology, 46(4), 456-460.

Olaoye, O.A., Onilude, A.A. and Dodd, C.E.R. (2008). Identification of Pediococcus spp. from beef and evaluation of their lactic acid production in varying concentrations of different carbon sources. Advances in Natural and Applied Sciences, 2(3), 197-207.

Oliveros, M.C.R., Manito, C.A., Del Barrio, A.N. and Lapitan, R.M. (2007). Proximate composition and intramuscular fatty acid profile of meat from Brahman-grade cattle (Bos indicus) and crossbred carabao (Bubalus bubalis L.). Philippine Journal of Veterinary and Animal Science, 33(1), 9-17.

Pegg, R.B. and Shahid, F. (2000). Nitrite curing of meat: The N-nitrosamine problem and nitrite alternatives. Trumbull, CT, USA: Food Nutrition Press.

Philippine Statistics Authority - Bureau of Agricultural Statistics. (2019). Carabao situation report from January to March 2019. Retrieved on May 2019 from Philippines Statistics Authority: https:// psa.gov.ph/livestock-poultry-iprs/carabao/inventory

Sanchez, P.C. (2008). Philippine fermented foods: principles and technology. Quezon City, Phillipines: University of the Philippines Press.

Simpson, B.K. (2012). Food Biochemistry and Food Processing., p. 284-424. USA: John Wiley and Sons, Inc. USA. https://doi.org/10.1002/9781118308035

Sumbali, G. and Mehrotra, R.S. (2009). Principles of Microbiology., p. 107-109. New Delhi, India: Tata McGraw Hill Education Private Ltd.

Toldra, F. and Flores, M. (1998). The role of muscle proteases and lipases in flavor development during processing of dry-cured ham. Journal of Food Science and Nutrition, 38(4), 331-352. https:// doi.org/10.1080/10408699891274237

Toldra, F., Hui, Y.H., Astiasaran, I., Sebranek, J. and Talon, R. (2014). Handbook of Fermented Meat and Poultry, $2^{\text {nd }}$ Ed. West Sussex, UK: John Wiley and Sons, Inc. https://doi.org/10.1002/9781118522653

Toldra, F. (2008). Handbook of Fermented Meat and Poultry., p. 125-131. UK: Wiley-Blackwell.

Veljovic, K., Fira, D., Vidojevic, A.T., Abriouel, H., Galvez, A. and Topisirovic, L. (2009). Evaluation of antimicrobial and proteolytic activity of Enterococci isolated from fermented products. European Food Research and Technology, 230(1), 63-70. https:// doi.org/10.1007/s00217-009-1137-6

Waterborg, J.H. (2002). The Protein Protocols Handbook., p. 7-9. USA: Springer.

Wood, B.J.B. and Holzapfel, W.H. (1995). The Genera of Lactic Acid Bacteria., p. 307-323. UK: SpringerScience+Bussinesss Media. https:// doi.org/10.1007/978-1-4615-5817-0

Zapelena, M.J., Zalacain, I., De La Peña, M.P., Astiassaran, I. and Bello, J. (1997). Addition of a neutral proteinase from Bacillus subtilis (neutrase) together with a starter to a dry fermented sausage elaboration and its effect on the amino acid profiles and the flavor development. Journal of Agricultural and Food Chemistry, 45, 472-475. https:// doi.org/10.1021/jf9602380 